\title{
PROPOSITION OF PICK \& WORK SYSTEM FOR APPLICATION IN MANUAL ASSEMBLY
}

\begin{abstract}
Many assembly processes in mechanical production systems have high share of manual operations. These manual operations can have big influence on final time and quality of production. Because the work is realized by human it is very important to take in account human properties and design the operation in way which will eliminate - mistakes and errors. To achieve this it is possible to use PokaYoke techniques and Pick-by systems. The paper describes the possibility of the use of these tools in assembly and proposes own Pick \& Work system concept for application in the assembly operations.
\end{abstract}

Keywords: assembly, Poka-Yoke, Pick-by systems

\section{Introduction}

Cost, quality and time play a crucial role in the competitive struggle. There are various tools and methods that are either focused on improving these parameters individually or globally. In order to ensure high quality production can be used Poka-Yoke access. It is a philosophy aimed at achieving one hundred percent quality. Within this philosophy it is possible to use various tools and techniques. The article describes the basics of the method, as well as the capabilities of the so-called Pick-by systems. It also introduces the concept of a system that uses basic philosophy Pick-by systems and is used for quality assurance at the assembly workstation.

Poka-Yoke is a Japanese term, which means „mistake-proofing”. The author of this approach is Japanese Shigeo Shingo [1]. Poka-Yoke is an integral part of Kaizen. The basic objective of Poka-Yoke is to achieve product faultlessness. It is an application of such relatively simple and effective measures that ensure that errors in the manufacturing and assembly process did not affect the quality of the final product. The basic principle of Poka-Yoke is the creation of

\footnotetext{
${ }^{1}$ Autor do korespondencji/corresponding author: Katarina Senderská, Technical University in Košice, Mäsiarska 74, 04001 Košice, Slovakia, tel.: +421 556023502, e-mail: katarina.senderska@tuke.sk

2 Albert Mareš, Technical University in Košice, Mäsiarska 74, 04001 Košice, Slovakia, e-mail: albert.mares@tuke.sk,
} 
tools, techniques and procedures so, that it is impossible or very difficult for workers to make a mistake. Basic principles:

- to prevent from mistakes is more important than to detect mistakes,

- to prevent from mistakes in the production and assembly,

- fast mistake detection at the point of origin,

- to avoid repeated mistakes and improper installation.

This means that in the process of production and assembly, the errors are not accepted, are not made, the defective parts do not continue in the manufacture and assembly process, origin of the mistakes is prevented by relatively simple technical measures and the mistake causes are eliminated. In the assembly it is mainly about:

- product design, that does not allow for improper assembly, part exchange, respectively part miss out and so on,

- assembly process, that is designed so, that cannot cause faults as for example opposite inserting, using of incorrect parts etc. and all this by various type of means respectively technical elements and equipments (fixtures, sensors and so on).

One of the advanced technologies are Pick-by respectively Pick-to systems such as: Pick-by-Light (Pick-to-Light), Pick-by-Voice, Pick-by-Vision, Pick $\&$ Work, and so on. Although the main area of their application is logistic, this technology has also interesting applications in assembly. The principle of function illustrates an example of Pick-to-Light system (Fig. 1). The basic principle of function of this system is display lights and buttons placed next to each pallet. After the order identifying e.g. by barcode scanning, appropriate pallet control lights will turn on and it indicates that this pallet contains the good, which should be taken. The display shows the number of units which should be taken from the pallet. A worker takes off a required number of pieces and presses a button to confirm that the task is fulfilled. After pressing the button the light turns off. Once no light is turned on, the worker knows that he has completed the order and may proceed to fulfill the next order. In some cases, the system is designed so, that instead of pressing the confirmation button is sensed
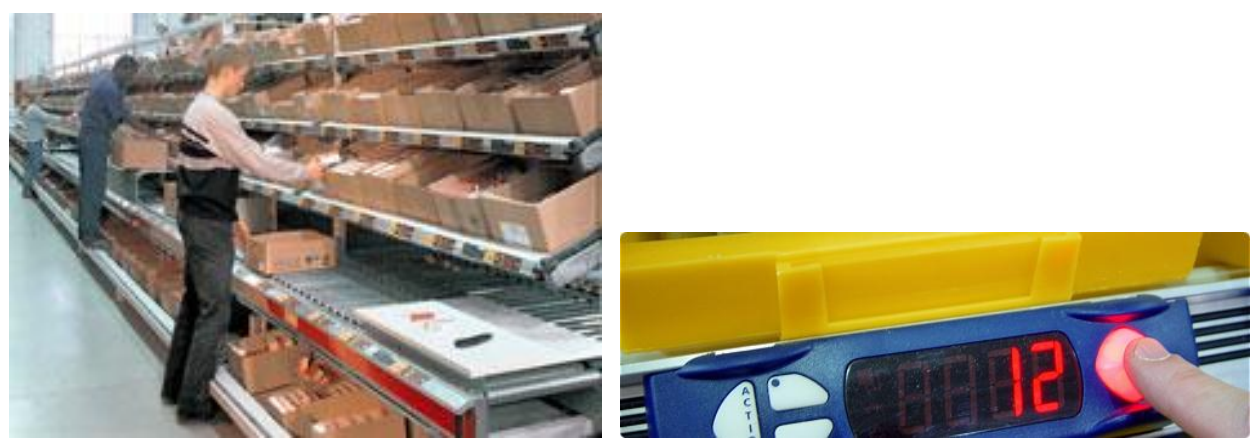

Fig. 1. Example of Pick-by-Light system, according to [2, 3] 
hand position and determine if a worker put his hand into the palette highlighted with light or not. If so this is signaled by illumination of green light. If the worker puts his hand into the wrong palette the red indicator will light on (Fig. 2).

Pick-by-Voice system works similarly, but instead of illuminating lights are used voice instructions that guide the operator to the pallet, and the number of pieces that need to be removed from the pallet. The operator confirms the performance of a task by saying a keyword or phrase into the microphone and then proceeds until it has fulfilled all the tasks related to a particular order. Pick-byVision system is based on the application of elements of Augemented Reality (Fig. 3). The operator has head mounted display in the form of glasses that allows him to see reality, but in this reality is projected information from a computer about the pallet positioning and about the number of units of the product which should be removed from the pallet.
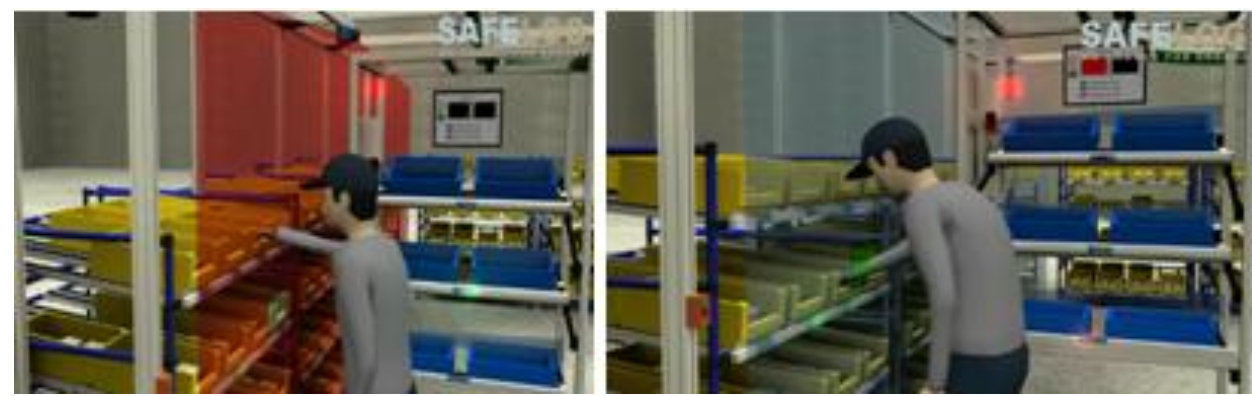

Fig. 2. Print screen from animation example Pick-to-Light system, according to [4]
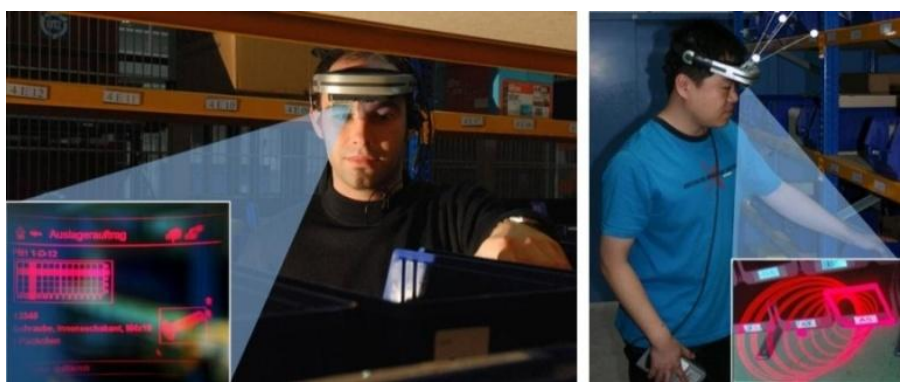

Fig. 3. Example of Pick-by-Vision, according to [5]

System Pick \& Work is directly designed for performing assembly operations. It is a concept from firm Schäfer (Fig. 4). Pick \& Work system is a system designed to eliminate worker's faults when removing components and parts from storage system, which is also applicable in the manual assembly. The principle is based on the assembly procedure performed in a special program. 
This process usually includes multimedia elements such as charts, pictures and videos that help the worker during assembly. Based on a special program the assembly procedure as well as any other data is defined. The worker receives on the touch screen the information about the assembly procedure step by step. The worker in addition to the assembly procedure will also receive the information about the position of related parts by lighting on the signal light. It also shows the number of components that worker needs. After the removing the component respectively components, the worker confirms part removing by pressing the button and then the light goes off. Then another light comes on to indicate another component in a container that should be taken in the next step of assembly.
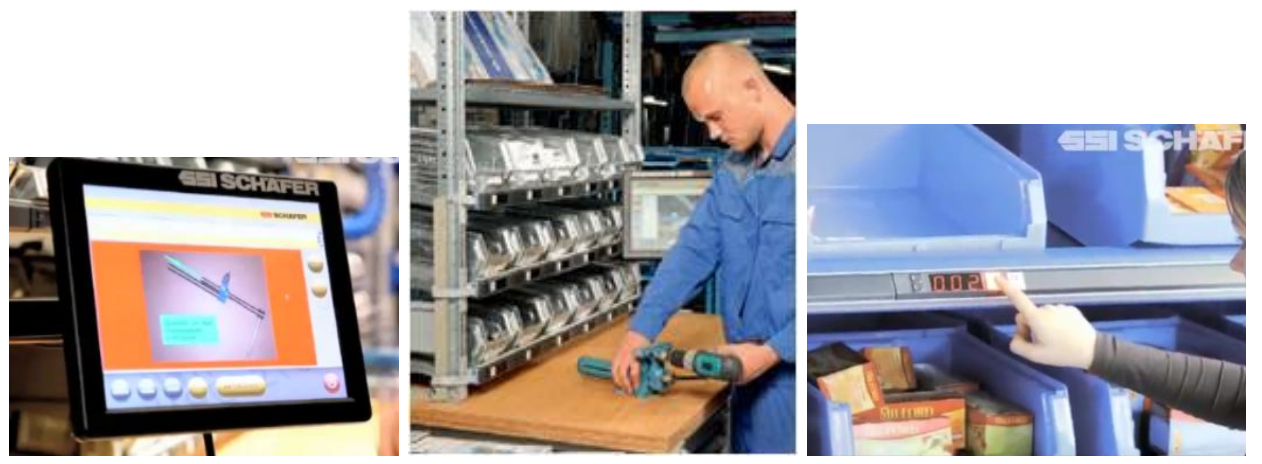

Fig. 4. Example of the Pick \& Work, according to [6]

\section{Pick \& Work system concept}

Within the framework of planned research and development of tasks was after studying the existing concepts and information proposed concept of laboratory accessorising by universal Pick \& Work system of own design. Essential requirements for this system are based on the needs of the laboratory and can be briefly specified as follows:

- modular concept in terms of both hardware and software, which allows for modification of type of assembly tasks,

- the possibility of incorporating into the complex system along with other planned elements such as workplace on-line analysis, video analysis, and so on.

Since the priority was focused on the assembly operations, the solution was based on the following theses:

- Pick \& Work system has its application also by activities that are not repeated i.e. the consecutive operations are not the same,

- in practice it is possible to meet with operations that are repeated due to the serial production - in this case, the Pick by system application would 
basically extend the work, because the worker is required to confirm the part removing from the pallet by button pressing,

- it is also likely that the worker who performs the assembly routine will take the parts from the pallets mechanically without looking respectively only with light view on the pallet in which the parts are located.

Simple Pick\&Work system consists of following components:

- module button bar in the number of 2 pieces at one workstation, each fixed at the follow up frame or at the rack,

- control unit for signal processing including software,

- touch display,

- connection to the master computer,

- electro installation of the system.

Module button bar (Fig. 5) contains five sets of Pick \& Work buttons with following functions:

- yellow button $(\mathrm{Y})$ - activates the Pick \& Work set - in the case that the button is off, the set is functionless and the button will not light,

- indication light at the button - red (R) indicates that it is necessary to take the part from the relevant container,

- green light $(\mathrm{G})$ - indicates the status O.K. - appears either after pressing the button or in case if the part is not in the order but system is ready,

- the window with the indication of the part number, that is necessary to take from the container.

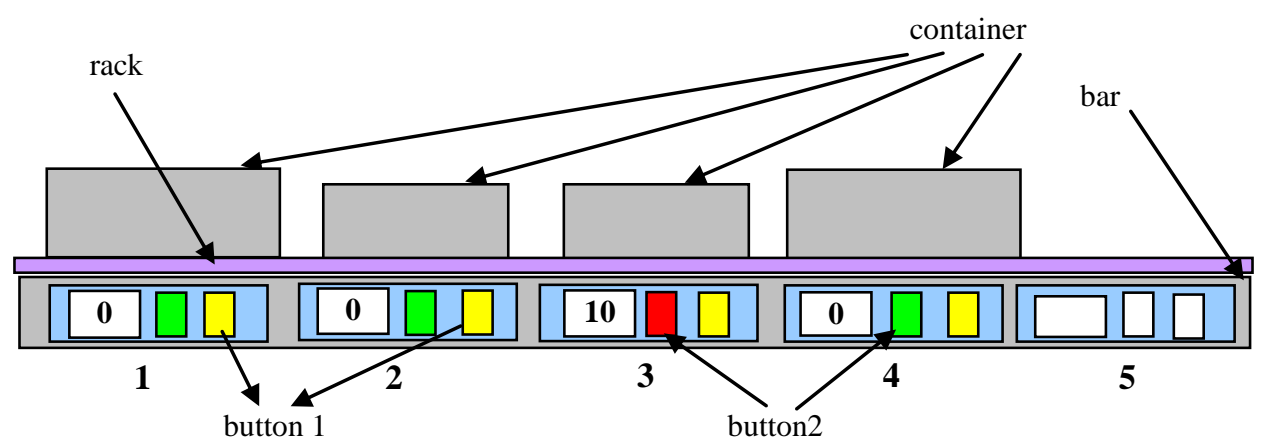

Fig. 5. Example of button bar for Pick \& Work system

At the bar according to the Fig. 5 are active 4 sets, the set 5 is not active - from the relevant container the parts are not taken up. The set 3 indicates that from the relevant container is necessary to take 10 parts. The set 1 and 2 are active - the lights indicate OK that for the worker means no activity requirement. The next planned workstation accessories are the buttons respectively the button box for indication of the assembly process, which should contain the button which: 
- indicates assembly start and assembly end,

- acknowledge button - the assembly was ok,

- button indicates, that the parts are at the input,

- button indicates, that the pars or the products are at the output.

In the Fig. 6 is presented an example of proposed assembly workstation accessories - module bar for Pick \& Work systems and the button box for indication of further five functions. This example was created in CATIA environment which is suitable to solve such type of tasks. Modelling of proposed concept allows to reduce errors during implementation of solution to reality and it is also consistent with nowadays trend in production system design.

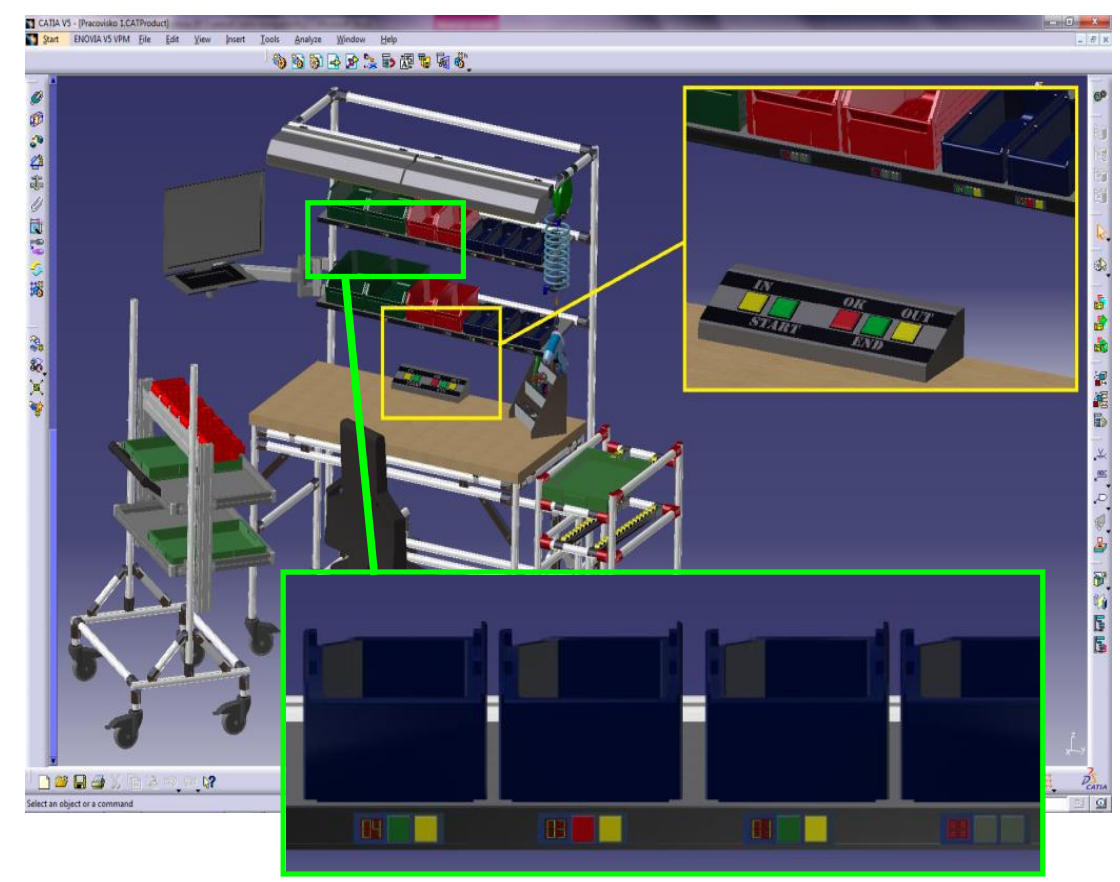

Fig. 6. Pick \& Work system integration into the assembly workstation, according to [7]

Activity at workstation with Pick \& Work system begins by uploading the data about product assembly procedure to the computer. Then the system can be used directly in assembly. At first the worker must choose a product which will be assembled. It is also necessary to put pallets with components on the site at appropriate places. Furthermore, it is necessary to activate all sets which will be active in this case. Assembly starts by pressing the button, input parts" if there are any. This is followed by pushing button „start assembly”. The worker proceeds on the basis of instructions, which are displayed on the screen and selects the relevant parts from pallets. If the product assembly or it parts is right, button 
OK is pressed. It also presses ,assembly completed” button and possibly button „product/parts output”, if these parts are really on output and they continue on another workstation or to the store. Throughout the all production period all relevant data are recorded, which can be processed and so on-line [8] and also after the assembly process finish.

\section{Conclusions}

The pursuit of so-called one hundred percent quality leads to the application of various tools and support systems. One of them is called Pick-by system. Of course, as with any other method it is also required before the initiation of this methodto consider the costs and benefits. At any rate, it can be concluded that to prevent errors is easier than removing them subsequently. On this philosophy is based the concept of the proposed system, which will monitor the rightness and regularity of parts taking sequence from pallets in the assembly process. In the building of planned laboratory stand it is also necessary to integrate this system into a comprehensive solution to create a methodology of on-line analysis of the assembly process.

\section{References}

[1] Molnár V., Fedorko G.: Catia - základy projektovania 2, TU, Košice 2007.

[2] http://www.dematic.com/puttolight (28.5.2011).

[3] http://www.kbs-gmbh.de/en/beleglose_kommissionierung/(28.5.2011).

[4] Safelog GmbH: http://www.safelog.de/(28.5.2011).

[5] Günthner W.A., Blomeyer N., Reif R., Schedlbauer M.: Pick-by-Vision: Augmented Reality unterstützte Kommissionierung, http://www.fml.mw.tum.de/fml/index. php?Set_ID=967.

[6] http://www.ssi-schaefer.de/en/workstation/products/workstation-systems.html.

[7] Horváth P.: Laboratórne pracovisko štíhlej montáže, Diplomová práca, $\mathrm{SjF} \mathrm{TU}$ v Košiciach, Košice 2013.

[8] Senderská K., Mareš A., Zajac J.: Hardware of manual assembly workstation online analysis, Sci. Bulletin: Series D: Mechanical Engineering, 74 (2012) 103-110.

\section{Acknowledgements}

This contribution is the result of the international project implementation: Hungary - Slovak Republic LEAN LAB HUSK/1101/1.6.1 supported by EU founds. 


\section{PROPOZYCJA SYSTEMU PICK \& WORK DO ZASTOSOWAŃ W MONTAŻU MANUALNYM}

\section{Streszczenie}

Większość procesów montażu w systemach produkcji mechanicznej składa się w znacznej części z operacji manualnych. Te operacje manualne mogą znacznie wpływać na końcowy czas i jakość produkcji. Ponieważ praca jest wykonywana przez człowieka, ważne jest uwzględnienie cech człowieka i projektowanie operacji, tak aby wyeliminować pomyłki i błędy. Aby to osiagnąć, możliwe jest użycie technik Poka-Yoke i systemów Pick-by. W pracy nakreślono możliwość wykorzystania tych narzędzi w montażu i zaproponowano system Pick \& Work do zastosowania w operacjach montażu.

Słowa kluczowe: montaż, Poka-Yoke, systemy Pick-by

DOI: $10.7862 / \mathrm{rm} .2013 .17$

Otrzymano/received: 14.05 .2013

Zaakceptowano/accepted: 25.07.2013 